\title{
o6.Yabancı dil olarak Türkçe öğrenen Cezayir'deki Türkoloji bölümü öğrencilerinin B1-B2 düzeyi yazılı anlatımlarının yanlış çözümlemesi yaklaşımıyla değerlendirilmesi
}

Mustafa EMEK1

APA: Emek, M. (2021). Yabancı dil olarak Türkçe öğrenen Cezayir'deki Türkoloji bölümü öğrencilerinin B1-B2 düzeyi yazılı anlatımlarının yanlış çözümlemesi yaklaşımıyla değerlendirilmesi. RumeliDE Dil ve Edebiyat Araştırmaları Dergisi, (24), 77-92. DOI: 10.29000/rumelide.990097.

$\ddot{\mathbf{O z}}$

Bu çalışmanın amacı yabancı dil olarak Türkçe öğrenen Cezayir 2 Üniversitesi Türkoloji Bölümü öğrencilerinin B1-B2 düzeyi yazılı anlatımlarını yanlış çözümlemesi yaklaşımıyla değerlendirmektir. Araştırma grubunu söz konusu bölümde B1-B2 düzeyi yabancı dil olarak Türkçe dersi alan 20 öğrenci oluşturmaktadır. Çalışmanın gerçekleştirilebilmesi için öğrencilerden serbest yazma etkinliği olarak akıllarında kalan bir anıy ya da bildikleri ve anlatmak istedikleri bir konuyu, haberi, durumu Türkçeyi kullanarak kompozisyon şeklinde yazmaları istenmiştir. Çalışmada nitel araştırma yaklaşımı kullanılmıştır. Doküman incelemesi araştırmanın yöntemi, veri toplama ve veri analizi aracı olarak kullanılmıştır. Verilerin analizinde doküman incelemesinin yanı sıra yanlış çözümlemesi ve içerik analizi tekniklerinden yararlanılmıştır. Öğrencilerin Türkçe imla, yazım ve noktalamada 92, dilbilgisinde 90, söz dizimde 40 ve sözcük seçiminde 25 olmak üzere toplam 337 yazılı anlatım yanlışı yaptıkları tespit edilmiştir. Diller arası olumsuz transfer kaynaklı yazılı anlatım yanlışları arasında Arapça ve Fransızcanın etkisiyle Türkçe cümle kurulumunda yapılan yanlışlar yer almaktadır. Öğrencilerin Türkçe ses bilgisiyle ilgili yaptıkları dil içi gelişimsel yanlışların olduğu ulaşılan bulgular arasındadır. B1-B2 düzeyi yabancı dil olarak Türkçe öğrenen Türkoloji bölümü öğrencilerine yönelik imla, yazım noktalama, dilbilgisi, söz dizimi ve sözcük kullanımı öğretimi konusunda yapılan etkinliklerin sayılarının arttırılması ve bu etkinliklerin çeşitlendirilmesi gerekmektedir. Diller arası karşılaştırmalı çalışmalara ağırlık verilmelidir.

Anahtar kelimeler: Cezayir, Türkçenin yabancı dil olarak öğretimi, Türkoloji, yanlış çözümlemesi, yazılı anlatım yanlışları

\section{The evaluation of b1-b2 level written expressions of Algerian Turcology department students learning Turkish as a foreign language using error analysis approach}

\footnotetext{
Abstract

The aim of this study is to evaluate the B1-B2 level written expressions of the students of the Turcology Department of the Algeria 2 University, who learn Turkish as a foreign language, with the approach of error analysis. The research group consists of 20 students who take Turkish as a foreign language at B1-B2 level in the aforementioned department. In order to carry out the study, the students were asked to write a memory or a topic, news or situation that they know and want to tell as a free writing activity in Turkish. Qualitative research approach was used in the study. Document analysis was used both as a research method and as a data collection tool. In the analysis of the data, document review,

Dr. Öğr. Üyesi, Kahramanmaras Sütçü İmam Üniversitesi, Eğitim Fakültesi, Türkçe ve Sosyal Bilgiler Eğitimi Bölümü, Türkçe Eğitimi ABD (Kahramanmaraş, Türkiye), mustafaemek5@gmail.com, ORCID ID: oooo-0oo2-7959-6235 [Araştırma makalesi, Makale kayıt tarihi: 25.06.2021-kabul tarihi: 20.09.2021; DOI: 10.2900o/rumelide.990097]

Adres | Address

RumeliDE Dil ve Edebiyat Araştırmaları Dergisi Osmanağa Mahallesi, Mürver Çiçeği Sokak, No:14/8 Kadıköy - ISTANBUL / TÜRKIYE 34714 e-posta: editor@rumelide.com

RumeliDE Journal of Language and Literature Studies Osmanağa Mahallesi, Mürver Çiçeği Sokak, No:14/8

Kadıköy - ISTANBUL / TURKEY 34714

e-mail: editor@rumelide.com, tel: +90 505 7958124, +90 216773 o 616 phone: +90 505 7958124, +90 2167730616
} 
The evaluation of b1-b2 level written expressions of Algerian Turcology department students learning Turkish as a foreign language using error analysis approach / M. Emek (pp. 77-92)

error analysis and content analysis techniques were used. It was determined that the students made a total of 337 written expression errors, 92 in Turkish spelling and punctuation, 90 in grammar, 40 in syntax and 25 in word selection. Written expression errors due to negative transfer between languages include mistakes made in Turkish sentence construction with the influence of Arabic and French. It is among the findings that students have intralinguistic developmental errors about Turkish phonetics. It is necessary to increase the number of activities on spelling punctuation, grammar, syntax and word use teaching for students of the Department of Turcology, who learn Turkish as a foreign language at B1-B2 levels, and these activities should be diversified. Comparative studies between languages should be emphasized.

Keywords: Algeria, error analysis, Turcology, Turkish language teaching as a foreign language, written expression errors

\section{Giriş}

Dil, insanın kendi iç dünyası ve yaşamını sürdürdüğü dış dünya ile iletişim kurma ve etkileşim sağlama aracıdır. İnsan gerek ana dilinde gerekse bildiği diğer dillerde dinlerken ve konuşurken sözlü, okurken ve yazarken yazılı olmak üzere iki formu kullanır. Dil gelişimi de önce sözlü yapının daha sonra ise yazılı yapının öğrenilmesi şeklinde gerçekleşir. Dinleme ile başlayan dil edinim ya da gelişim süreci konuşma ve okuma ile devam eder ve son olarak yazma becerisinin öğrenilmesiyle tamamlanır. Yazma becerisinin öğrenmede son sırada yer alması rastlantısal değildir. Bir dilde yazılı ürün ortaya koymak üst düzey zihinsel becerilerin kullanıldığı karmaşık işlemler sürecinin gerçekleşmesi ile mümkün olmaktadır. Ayrıca dinleme, konuşma ve okuma becerilerinde yeterli olmak yazma becerisinde başarılı olmanın ön şartıdır. Dil becerilerinin herhangi biriyle ilgili yetersizlik diğer becerileri de olumsuz etkilemektedir. Okul öncesi dönemde ana dili edinimi sırasında doğal bir ortamda kendiliğinden dilin sözlü formu ile ilgili yapıları geliştiren birey okulla birlikte yazılı formuyla ilgili olan ve öğrenme olarak ifade edilebilecek yapıları kazanır. Öğrenilen ana dili çoğunlukla içinde yaşanılan toplumun günlük konuşma dili olduğundan insan bu dil ile ilgili öğrendiklerini uygulama konusunda sorun yaşamaz. Yabancı dilde yazma becerisi gelişimi açısından durum ve şartlar farklıdır. Hem bu becerinin geliştirilmesi hem de uygulanması çoğu zaman ana dilindeki kadar kolay olmayabilir. İmkanlar ve zaman daha sınırlı olabilir. $\mathrm{Bu}$ durum da öğrenilmesi zaten zor ve karmaşık olan yazma becerisinin geliştirilmesini daha zor hale getirebilir. Yabancı dil öğretim programlarının dil öğretiminde önceliği dilin yazılı formunun öğretilmesine veren geleneksel öğretim yaklaşımlarının etkisiyle hazırlanması (Doğuman, 1983) öğrencinin zorluk derecesine göre sıralanmış dil becerilerinin öğrenimine sondan yani en zor olandan başlamasına neden olduğundan konuyu daha da içinden çıkılmaz hale getirebilmektedir. Dolayısıyla yabancı dil öğretiminin çağdaş öğretim yaklaşımları esas alınarak dilin öncelikle sözlü daha sonra yazılı formunun öğretildiği bir yapıda gerçekleştirilmesi yazma becerisinin öğretimi açısından da yararlı olacaktır (Doğuman, 1983). Burada kastedilen becerilerin sırayla birer birer öğretilmesi ve bir beceri öğretilmeden diğer becerinin öğretilmesine geçilmemesi değildir. Bütün dil becerileri bir arada öğretilmelidir. Ancak ağırlıklı öğretilen ya da öğretimine öncelik verilmesi gereken beceri değissiklik gösterebilir. Aynı durum Türkçenin yabancı dil olarak öğretiminde yazma becerisinin kazandırılmasıyla ilgili de geçerlidir.

Türkçe Türkiye'de ve Türkiye dışında farklı amaçlarla, farklı öğrenci gruplarına yabancı dil olarak öğretilmektedir. Türkçenin yabancı dil olarak öğretimiyle ilgili yapılan araştırmaların artması bu konuda başarılı çalışmalar yapılmasını sağlayacaktır. Yazma becerisinin kazandırılmasıyla ilgili farklı çalışma grupları, evren örneklem ve bağlamları kapsayan çalışmalar bu konuda yaşanan sorunların

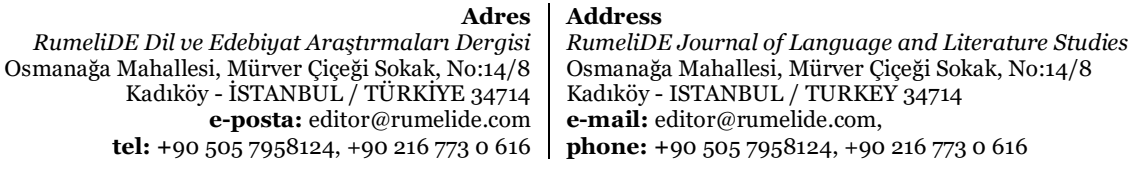


çözülmesine yol gösterecektir. Çünkü öğrencilerin Türkçe yazma becerisine yönelik ortaya koyacakları ürünler onların Türkçe yeterliliklerini ortaya koyacaktır. Ayrıca yazılı anlatımla ilgili öğrencilere ait veriler öğretmenlere geçerli ve güvenilir ölçme değerlendirme yapma imkânı sunacaktır. Özellikle yazma becerisinin öğretimi sırasında öğrencilerin yaptıkları yanlışların incelendiği çalışmalar alanla ilgili gerçek geri dönütler sağlaması açısından önemlidir. Çünkü yanlışın nedeni kişinin konuyla ilgili doğru bilgi sahibi olmamasıdır ve bu anlamda "yanlış" kavramı kişinin doğrusunu bildiği konularda yorgunluk ya da dalgınlık sonucu yaptığı davranışları anlatmak için kullanılan "hata" kavramından ayrılır (Ellis, 1997; Erdoğan, 2005). Bu bağlamda yanlışların esas alındığı çalışmaların öğrenme eksiklerinin ortaya çıarılmasını sağlayacağını söylemek mümkündür. Lado (1957) ve Richards (1974) ikinci veya yabancı dil öğrenilirken yapılan yanlışların nedenini ana dilinin yapısını ve kültürünü öğreneceği dile taşıma eğiliminde olan öğrenenin ana dilinden getirdiği yapılarla açıklamaktadır. Onlara göre ikinci ya da yabancı dile ana dilinden taşınan kurallar, olumsuz aktarımlar bu dilde yanlış yapılmasına neden olmaktadır. Erdoğan (2005) ise öğrenci tarafından yapılan bazı yanlışların kolaylıkla düzeltileceğini ancak bazı yanlışların ise daha kalıcı olduğunu ve düzeltilmesinin zaman alacağını belirtmektedir. İkinci veya yabancı dil öğretiminde yanlışlara yönelik yapılan araştırmaların önemine dikkat çekmektedir. Hendrickson (1980) ikinci veya yabancı dilde yapılan yanlışları, öğrenenin ana dilindeki düşünce sistemini öğrendiği dile taşımaya çalışmasıyla açıklar. Yabancı dil öğretiminde yazılı anlatım yanlışları üzerine yapılan çalışmaların konuya katkı sağlayıcı özelliğinin olması bütün bu araştırmaların ortak noktasını oluşturmaktadır. Corder (1981, s. 10-11) yanlışların tespit edilmesinin öğretmenlere öğrencilerin durumuyla ilgili bilgi vereceğini, öğrencilerin öğrendikleri dilin yapısını keşfetmelerini sağlayacağını ve araştırmacılara yabancı dil öğretimi ve öğrenimiyle ilgili veri sağlayacağını belirtir.

Yanlış çözümlemesi yabancı dil öğretiminde yanlışların esas alındığı çalışma yaklaşımlarından biridir. Yanlış çözümlemesiyle ilgili Türkiye'de yapılan ilk çalışmalardan biri olan ve konuyla ilgili kapsamlı açılayıcı bilgi içeren Dede (1983)'nin araştırmasından hareketle yanlış çözümlemesiyle ilgili şunlar söylenebilir: İkinci dil öğrenimi sırasında yapılan yanlışların kaynağının ana dilinden yapılan olumsuz transferler olduğu düşüncesi karşıtsal çözümleme yaklaşımının doğmasına neden olmuştur. Bu yaklaşımla kaynak dil ile hedef dil karşılaştırmalı olarak ele alınmakta ve hedef dilin öğrenimi sırasında yapılan yanlışlara gerekçe olarak kaynak dilden yapılan olumsuz aktarımlar gösterilmektedir. Bir süre sonra ortaya çıkan ve hedef dil öğreniminde yapılan yanlışların tek kaynağının ana dili olmayabileceği fikri yanlış çözümlemesinin karşıtsal çözümlemeye alternatif olarak gelişmesini sağlamıştır. Yanlış çözümlemesi hedef dil ile ilgili yanlışların ana dili kaynaklı olabileceği gibi hedef dil ile ilgili dil içi gelişimsel yanlışlar kaynaklı da olabileceği esasına dayanmaktadır. Yanlış çözümlemesiyle bir anlamda hedef dil ile ilgili öğrencinin yaptı̆̆ı öğrenmeler değerlendirilmektedir. Süreç sadece diller arasındaki benzerlik ve farklılıkların yanlışlara neden olabileceği düşüncesinden kurtarılmaktadır. Yanlış çözümlemesiyle birlikte öğrencilerden elde edilen veriler incelenmeye alınmaktadır. Bu yönüyle yanlış çözümlemesinin karşıtsal çözümlemeyi tamamlayan bir yönünün olduğunu söylemek mümkündür (Dede, 1983, s.123).

Yanlış çözümlemesi çalışmalarıyla bilinen Richards (1974, s. 176-178) ikinci, yabancı dil öğreniminde görülen ve hedef dil ya da öğrenilen dil kaynaklı olan dil içi gelişimsel yanlışları aşırı genelleme, kural kısıtlamayı bilmeme, yanlış kavram geliştirme ve kuralları eksik uygulama olarak sınıflamıştır. $\mathrm{Bu}$ çalışmada dil içi gelişimsel yanlışların tespiti ve değerlendirilmesinde Richards'ın bu sınıflaması esas alınmıştır. Ayrıca karşıtsal çözümlemenin esasını oluşturan ve diller arası aktarım yanlışları olarak tanımlanan öğrencilerin bildikleri, kaynak dillerden öğrendikleri hedef dile yani Türkçeye yaptıkları olumsuz dil bilgisi transferleri kaynaklı yanlışların değerlendirilmesi bu araştırmanın bir diğer boyutudur. B1-B2 düzeyi yabancı dil olarak Türkçe öğrenen Cezayir 2 Üniversitesi Türkoloji bölümü

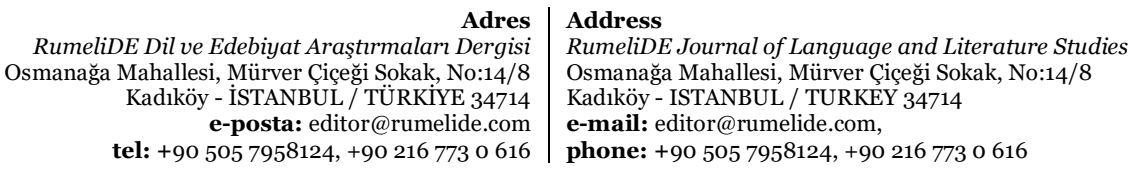


The evaluation of b1-b2 level written expressions of Algerian Turcology department students learning Turkish as a foreign language using error analysis approach / M. Emek (pp. 77-92)

öğrencilerinin yaptıkları yazılı anlatım yanlışları öncelikle tespit edilmiş ve konu alanlarına göre sınıflandırılmıştır. Daha sonra ise bu yanlışların öğrencilerin bildikleri, kaynak dilden kaynaklı olanlarıyla Türkçe ile ilgili öğrenme eksikliğinden dolayı olanlar tespit edilip sınıflandırılmıştır. Bu yanlışların nedenlerine ve çözümlerine yönelik geliştirilen öneriler ise çalışmanın son kısmında verilmiştir.

\section{Araştırmanın önemi}

İkinci, yabancı dil öğretiminde öğrencilerin yanlışlarının tespitine ve değerlendirilmesine yönelik çalışmalar hem öğrenci hem de öğretmen ve araştırmacı için olumlu geri dönütler sağlamaktadır. Bu tür çalışmalar aynı zamanda uygulanan öğretim programlarının etkililiğini, eksiklerini göstermesi açısından da önemlidir. Türkçenin yabancı dil olarak öğretiminde yazılı anlatım yanlışlarına yönelik tespit ve değerlendirme çalışmalarının yapılması ve yapılan çalışmalarda araştırma grubu, katılımcı çeşitliliğ̈inin sağlanması her bir öğrenci grubunun ihtiyaçlarının tespit edilmesine ve onlara yönelik doğru öğretim programlarının oluşmasına katkı sağlayacaktır. Aynı zamanda Türkçenin yabancı dil olarak farklı dil gruplarına ve farklı ihtiyaçlara, niteliklere sahip öğrenci gruplarına öğretimi konusunda bir standardın oluşması sağlanacaktır.

Alan yazında Türkçenin yabancı dil olarak öğretiminde yapılan yazılı anlatım yanlışlarına yönelik çalışmalara bakıldığında Türkiye'deki üniversitelerin Türkçe öğretim merkezlerinde farklı düzeylerde yabancı dil olarak Türkçe dersi alan öğrencilere yönelik bu tür çalışmaların gerçekleştirildiği görülmüştür. Ayrıca Yunus Emre Enstitüsünün çeşitli ülkelerdeki Türk Kültür Merkezlerinde yabancı dil olarak Türkçe dersi alan farklı düzeylerdeki öğrencilere yönelik de bu tür çalışmaların yapıldığı tespit edilmiştir. Yazılı anlatımların yanlış çözümlemesi yaklaşımıyla değerlendirildiği çalışmaların sayısı daha az olmakla birlikte bu tür çalışmaların araştırma gruplarını da benzer bağlamlardaki öğrenciler oluşturmaktadır. Subaşı (2010) yanlış çözümlemesi kullanarak Ankara Üniversitesi Tömer'de yabancı dil olarak Türkçe öğrenen Arap öğrencilerin kompozisyonlarını değerlendirmiştir. Bu çalışma alanda yanlış çözümlemesi kullanılarak yabancı dil olarak Türkçe öğrenen öğrencilerin yazılı anlatımlarının değerlendirildiği ilk çalışmalardandır ve konuya dikkat çekmesi bakımından önemlidir. Ankara Üniversitesi Tömer'de 2009 yllında yabancı dil olarak Türkçe dersi alan bir grup Arap öğrenci ile sınırlıdır. Belirtilen nitelikleri taşıyan bir diğer çalışma ise Bölükbaş (2011) tarafından yapılmıştır. Bu çalışmada da İstanbul Üniversitesi Tömer'deki yabancı dil olarak Türkçe öğrenen 20 Arap öğrencinin yazılı anlatımları yanlış çözümlemesi yaklaşımıyla değerlendirilmiştir. Çalışma öğrencilerin yanlışlarına Arapça-Türkçe karşılaştırmalı bir yaklaşım getirmesi ve detaylı bir inceleme sunması bakımından önemlidir. Her iki çalışmanın araştırma grubunu da Arap öğrenciler oluşturmakla birlikte öğrencilerin geldikleri ülkeler, Türkçe yeterlilikleri ve yaptıkları yanlışlar değişiklik göstermektedir. Daha sonra Büyükikiz ve Hasırcı (2013) Gaziantep Üniversitesi Tömer'de B2 seviyesinde yabancı dil olarak Türkçe öğrenen 42 öğrencinin yazılı anlatımlarını yanlış çözümlemesi yaklaşımıyla incelemişlerdir. Bu çalışma araştırma grubunu oluşturan öğrencilerin farklı ülkelerden gelmiş olmaları, ana dillerinin farklı olması ve hepsinin B2 düzeyi Türkçe öğreniyor olmaları yönlerinden önceki iki çalışmadan farklıdır. Dolayısıyla elde edilen veriler de bu doğrultuda farklılık göstermektedir. Kayhan (2014) ise Tahran Yunus Emre Türk Kültür Merkezinde B2 düzeyi yabancı dil olarak Türkçe öğrenen 71 öğrencinin yazılı anlatımlarını yanlış çözümlemesi yaklaşımıyla değerlendirmiştir. Bu çalışma araştırma grubu olarak İran bă̆lamını ve ana dili Farsça olan öğrenci grubunu esas alması, öğrencilerin B2 düzeyi Türkçe öğreniyor olması ve kültürel anlamda Türkiye ile yoğun etkileşimlerin olduğu bir ülkeyi kapsıyor olması bakımından önemlidir. Dolayısıyla çalışma alana konuyla ilgili farklı bir araştırma grubu ve bağlamdan veri sağlamıştır. Çetinkaya (2015) çalışmasında Gaziantep Üniversitesi Tömer'de B2 düzeyi yabancı dil

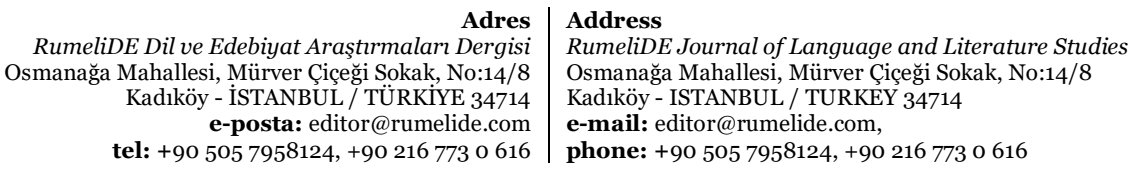


olarak Türkçe öğrenen 50 öğrencinin yaptıkları yazılı anlatım yanlışlarını dilsel, bilişsel işlemleme ve iletişimsel özelliklere göre yanlış çözümlemesi yaklaşımını kullanarak betimlemiştir. Bu çalışma Gaziantep Üniversitesi Tömer örnekleminde gerçekleşen ikinci çalışma olmakla birlikte araştırma grubunun farklı olması ve yanlış çözümlemesi yaklaşımının kullanıldığı çalışmalara farklı bir yön kazandırması nedeniyle önemlidir. Çalışmada yanlışlar farklı bir sınıflama yapılarak ve farklı bir değerlendirmeyle ele alınmıştır. Yılmaz ve Bircan (2015) çalışmalarında Gaziosmanpaşa Üniversitesi Tömer'de A2 düzeyi yabancı dil olarak Türkçe öğrenen 22 öğrencinin kompozisyonlarını yanlış çözümlemesi yaklaşımıla değerlendirmişlerdir. Öğrencilerin dil içi gelişimsel yanlışlarının değerlendirildiği çalışma gerek incelenen düzey gerekse çalışma grubunun farklılığı dolayısıyla konuya katkı sağlar niteliktedir. Çerçi, Derman ve Bardakçı (2016) yine Gaziantep Üniversitesi Tömer'de farklı ülkelerden gelen 14 öğrencinin yazılı anlatımlarını yanlış çözümlemesi yaklaşımıyla değerlendirmişlerdir. Bu çalışmanın önceki çalışmalardan farkı ve alana katkısı aynı öğrencilerin A1 kurundan C1 kuru bitimine kadar kur bitirme sınav kağıtlarını incelemesi böylece değerlendirmede bir süreklilik ya da uzun süreli değerlendirme sağlaması olarak açılanabilir. Önder ve Yıldız (2017) ise çalışmalarında İzmir Dokuz Eylül Üniversitesi Dil Eğitimi Uygulama ve Araştırma Merkezinde yabancı dil olarak Türkçe dersi alan ve farklı düzeylerde üniversite eğitimi alan farklı ülkelerden gelen 65 öğrencinin A1, B1 ve B2 düzeyi kur bitirme sınav kağıtlarını yanlış çözümlemesi yaklaşımıyla değerlendirmişlerdir. Araştırma grubunun ve değerlendirmeye alınan kur düzeyinin çok katmanlı olması ve çalışmada karşılaştırmalı bir değerlendirme yapılması çalışmanın konuya katkı sağlayan yönlerindendir. Son olarak Boylu, Güney ve Özyalçın (2017) İstanbul Aydın Üniversitesi Tömer'de B1 düzeyi yabancı dil olarak Türkçe öğrenen farklı ülkelerden 50 öğrencinin yazılı anlatımlarını yanlış çözümlemesi yaklaşımıyla değerlendirmişlerdir. Çalışma araştırma grubunu oluşturan öğrencilerin çeşitliliği ve elde edilen verilerin farklılı̆̆ bakımından önemlidir.

Alan yazına bakıldığında Türkçenin yabancı dil olarak öğretiminde yazılı anlatımların yanlış çözümlemesiyle değerlendirilmesine yönelik çalışmaların genellikle Türkiye ile sınırlı olduğu yurt dışında yapılan çalışmaların da Türkiye'nin yurt dışında faaliyet gösteren kurumlarında yapıldığı görülmektedir. Yine yapılan çalışmaların araştırma gruplarını oluşturan öğrencilerin genellikle çeşitli bölümlerde üniversite eğitimi almak için Türkiye'ye gelen ve Türkçe öğrenen öğrenciler olduğu görülmektedir. Bu çalışma konuyla ilgili Türkiye dışında ve başka bir ülkeye ait bir kurumda yapılmış olması bakımından önemlidir. Ayrıca çalışma grubunu oluşturan öğrencilerin tamamının Türkoloji bölümü öğrencisi olması bu çalışmanın daha önce konuyla ilgili yapılan çalışmalardan bir diğer farkıdır. Çalışmanın Cezayir'de gerçekleştiriliyor olması, çalışmaya katılan Cezayirli öğrencilerin çok dilli olmaları ve Türkoloji bölümü lisans öğrencisi olmaları toplanan verilerin ve ulaşılan sonuçların alana katkısı bakımından önemlidir. Ayrıca çalışmada öğrencilerin sadece dil içi gelişimsel yanlışlarının değil diller arası olumsuz aktarım yanlışlarının da ele alınması konuyla ilgili alan yazına katkı sağlayacağı düşünülen bir diğer durum olarak ifade edilebilir.

\section{Araştırmanın amacı}

Bu çalışmanın amacı B1-B2 düzeyi yabancı dil olarak Türkçe öğrenen Cezayir 2 Üniversitesi Türkoloji Bölümü öğrencilerinin yazılı anlatım yanlışlarını tespit etmek, sınıflamak ve çözümlemektir. Yapılan çözümleme sonucunda yanlışların nedenleriyle ilgili çıkarımlar yapmak ve konuya ilişkin çözüm önerileri sunmak da bu çalışmanın amaçları arasındadır. Söz konusu amaçlardan hareketle araştırmada cevap aranacak soruları şu şekilde sıralamak mümkündür:

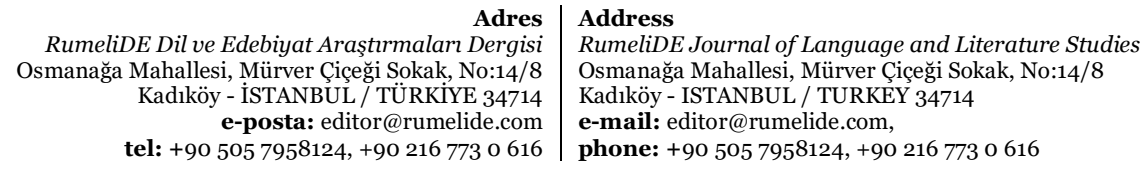


1.Türkoloji bölümü öğrencilerinin B1-B2 düzeyi yabancı dil olarak Türkçe yazılı anlatımda yaptıkları yanlışların dağılımı nasıldır?

2.Türkoloji bölümü öğrencilerinin B1-B2 düzeyi yabancı dil olarak Türkçe yazılı anlatımda yaptıkları diller arası aktarım yanlışlar nelerdir?

3.Türkoloji bölümü öğrencilerinin B1-B2 düzeyi yabancı dil olarak Türkçe yazılı anlatımda yaptıkları dil içi aktarım yanlışlar hangileridir?

\section{Yöntem}

$\mathrm{Bu}$ çalışma nitel araştırma yaklaşımı kullanılarak tasarlanmıştır. Çalışmada araştırılması planlanan konularla ilgili bilgi içeren yazılı materyallerin araştırma soruları bağlamında analizi söz konusu olduğundan doküman incelemesi yöntemi kullanılmıştır (Yıldırım \& Şimşek, 2013, s. 217). Eğitim bilimi araştırmalarında doküman incelemesini ağırlıklı bir biçimde kullanmaya yönelten durumlarda araştırmacı doküman analizi yöntemini esas alarak araştırmasını kurgulayabileceği gibi araştırmasında diğer veri toplama araçlarıyla birlikte doküman analizini de kullanabilir (Ulutaş, 2015, s. 288). "Doküman incelemesi veya analizi tek başına bir araşttrma yöntemi olabileceği gibi diğer nitel yöntemlerin kullanıldığı durumlarda ek bilgi kaynağı olarak da kullanılabilir.” (Tanrı̈ğğen, 2012, s.239). "Belgesel tarama ile yapılan araştırmalarn özgün (orijinal) olmayacağı bazılartnca ileri sürülmekte ise de neyin özgün sayılması gerektiği sorusu tartışmaya açıtır.” (Karasar, 2009, s. 184). Doküman tekniğine ihtiyaç duyulmasının en belirgin iki nedeninden biri başka teknikleri kullanarak araştırmanın yapılmasının mümkün olmamasıdır (Ekiz, 2009, s. 70). "Dokümanlar sadece onlardan öğrenilebilecek şeyler olduğu için değil aynı zamanda sadece doğrudan gözlem ve mülakat yoluyla elde edilebilecek bir araştırmanın yolunu da belirlediği için değerlidir.” (Patton, 2014, s. 294). Yöntemle ilgili yukarıda verilen ilgili literatür ve çalışmada kullanılan ağırlıklı metodun doküman incelemesi olması, başka yöntem kullanılarak araştırmayı gerçekleştirmenin mümkün olmaması nedeniyle çalışmanın yöntemi doküman incelemesi olarak belirlenmiştir. Doküman incelemesi yöntemi kullanılarak şekillenen araştırmada öğrencilerin Türkçe yazılı anlatım yanlışlarına yönelik tespit yapma ve değerlendirmede bulunma amacı güdülmektedir. Ayrıca yanlışların nedenleri ve çözümlerine yönelik önerilere yer verilecektir.

\section{Araştırma grubu}

Çalışmanın araştırma grubunu Cezayir 2 Üniversitesinde B1-B2 düzeyi yabancı dil olarak Türkçe öğrenen 12 kız, 8 erkek Türkoloji bölümü öğrencisi oluşturmaktadır. Öğrenciler Cezayir'in resmi dili ve aynı zamanda eğitim dili olan Arapça ve Fransızcayı bilmektedirler. Hatta araştırmacı tarafından yapılan gözlemlerle tespit edildiği üzere araştırma grubunu oluşturan öğrenciler tıpkı diğer Cezayirliler gibi aralarında iletişim ve etkileşim kurmak için çoğunlukla "Derce" olarak adlandırılan ve kreol olarak tanımlayabileceğimiz Arapça-Fransızca karışımı bir dili kullanmaktadırlar. Bunun yanı sıra üniversiteye gelene kadar resmi eğitim kurumlarında yabancı dil olarak İngilizce, Fransızca, İspanyolca, Çince, Korece, Rusça, İtalyanca dillerinden biri ya da birkaçı ile ilgili seçmeli dersler almaktadırlar. Her bir öğrenci Arapça ve Fransızcanın yanı sıra bu seçmeli dillerden birini ya da birkaçını farklı yeterlilik düzeylerinde bilmektedir. Bu anlamda öğrencilerin çok dilli olduklarını söylemek mümkündür. Dil öğrenimiyle ilgili böyle bir alt yapı ve öğrenme geçmişine sahip olan öğrenciler Türkoloji alanında lisans eğitimi alarak uzman olmak üzere yabancı dil olarak Türkçeyi öğrenmektedirler.

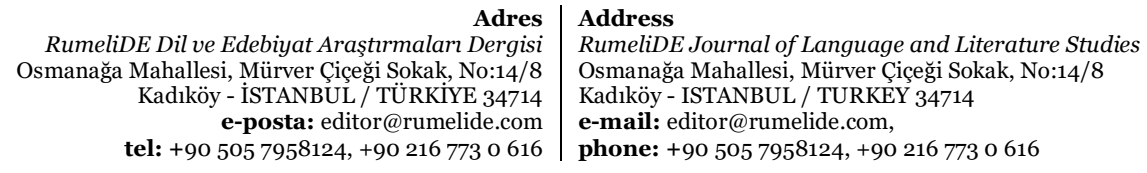




\section{Verilerin toplanması}

Araştırma verilerinin toplanmasında doküman incelemesi tekniği kullanılmıştır. Çalışmanın gerçekleştirilebilmesi için öğrencilerden serbest yazma etkinliği olarak akıllarında kalan bir anıyı ya da bildikleri ve anlatmak istedikleri bir konuyu, haberi, durumu Türkçeyi kullanarak kompozisyon şeklinde yazmaları, bu özellikleri taşıyan birer metin oluşturmaları istenmiştir. Bu metinler doğrudan öğrenciler tarafından oluşturulmaları nedeniyle birincil veriler olarak değerlendirilmektedir ve birincil verilerin toplanmasıyla ilgili çalışmanın amacına, mevcut kaynaklara ve araştırmacının becerilerine göre birçok yöntem kullanılabilir (Kumar, 2011, s. 147). Araştırmada takip edilen veri toplama ve analiz süreci basamakları şu şekildedir:

1.Öğrencilere verilen konuda metinlerin yazdırılması

2.Metinlerin araştırmacı tarafından toplanması ve numaralandırılarak okunması

3.Tespit edilen yanlışların araştırmacı tarafından hazırlanan tabloya göre kodlanması

4.Verilerin içerik analizine uygun olarak incelenmesi ve belirlenen başlıklara uygun olarak yanlış dağılımının tespiti

5.Verilerin yanlış çözümlemesi yaklaşımına uygun olarak incelenmesi ve yaklaşım çerçevesinde belirlenen başlıklara uygun olarak yanlış dağılımının tespiti

\section{Verilerin analizi}

Çalışmada toplanan verilerin analizinde doküman incelemesi, içerik analizi ve yanlış çözümlemesi kullanılmıştır. İçerik çözümlemesi belgelerdeki belli bakış açılarını, felsefeleri, dil ve anlatım gibi özellikleri derinlemesine ve belirli ölçütlerle yapılacak çözümlemelerle anlama çabasıdır (Karasar, 2009, s. 184). Bu çalışmada da içerik analizi kullanılarak öğrencilerin kullandıkları yazılı dil ve anlatımları yanlış çözümlemesi yaklaşımı aracılığıyla belirlenen ölçütlerden hareketle çözümlenmeye, incelenmeye, değerlendirilmeye çalışılmıştır.

Araştırmada öğrencilerin yazılı anlatımlarında tespit edilen yanlışlar öncelikle dilbilgisi yanlışları, söz diziminden kaynaklı yanlışlar, sözcük seçiminden kaynaklı yanlışlar, yazım ve imla yanlışları olarak sınıflanmış ve değerlendirilmiştir. Daha sonra yanlış çözümlemesi yaklaşımı gereği bu yanlışlar olumsuz aktarım yanlışları ve dilsel gelişim yanlışları olarak tekrar gruplandırılmış ve değerlendirilmiştir.

\section{Bulgular}

\section{Birinci araştırma sorusuna yönelik bulgular}

Öğrenciler tarafından oluşturulan yazılı metinlerin incelenmesi sonucunda $12 \mathrm{klz}, 8$ erkek toplam 20 öğrenciye ait 337 yanlış tespit edilmiştir. Öğrencilerin Türkçe yazılı anlatımlarında yaptıkları yanlışların dağılımının nasıl olduğuna yönelik araştırma sorusuna ilişkin bulgular Şekil ı'de gösterilmektedir.

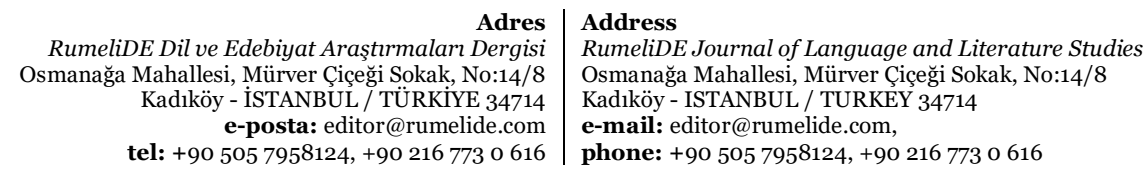


The evaluation of b1-b2 level written expressions of Algerian Turcology department students learning Turkish as a foreign language using error analysis approach / M. Emek (pp. 77-92)

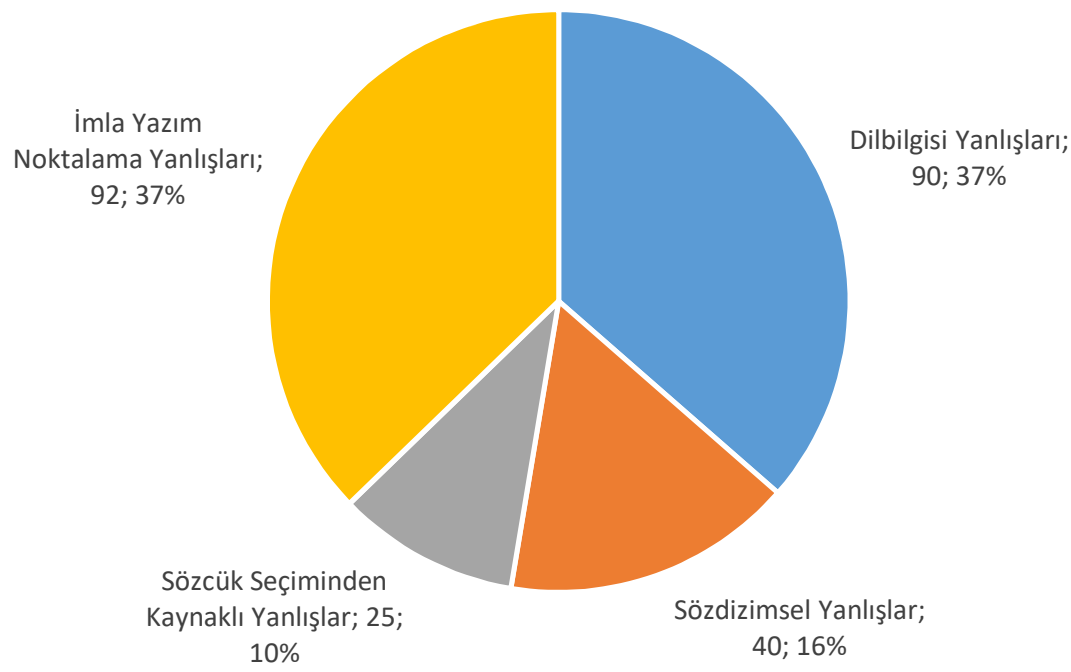

Şekil 1. Yazılı Anlatım Yanlışlarının Dağılımı

Şekil 1 incelendiğinde öğrencilerin dilbilgisi, imla, yazım ve noktalama yanlışlarının diğerlerinden fazla olduğu görülmektedir. Öğrencilerin Türkçe dilbilgisi alanında 90 yanlış yaptıkları ve bu yanlışların toplam yanlışların \%37'sini oluşturduğu tespit edilmiştir. Yapılan yanlışların yine \%37'sini ise tespit edilen 92 yanlış ile imla, yazım ve noktalama yanlışlarının oluşturduğu görülmektedir. Öğrenciler Türkçe söz dizimi alanında 40 yanlış yapmışlardır. Bu yanlışlar da toplam yapılan yanlışların \%16'sını oluşturmaktadır. Öğrencilerin en az yanlış yaptığı alan sözcük seçimidir. Öğrenciler yazılı metinlerinde sözcük seçiminden kaynaklı 25 yanlış yapmışlardır. Yapılan bu yanlışlar toplam yanlışların \%10’luk dilimini oluşturmaktadır.

B1-B2 düzeyi yabancı dil olarak Türkçe öğrenen Cezayir 2 Üniversitesi Türkoloji bölümü öğrencilerinin yazılı anlatım yanlışlarının alanlara ve alt alanlara göre dağılımı ise Tablo 1'de verilmektedir.

Tablo 1.Yazılı anlatım yanlı̧̧ı yapılan konular

\begin{tabular}{llll}
\hline $\begin{array}{l}\text { A.Dilbilgisi Yanlışları } \\
(90)\end{array}$ & $\begin{array}{l}\text { B.Sözdizimsel } \\
\text { Yanlışlar (40) }\end{array}$ & $\begin{array}{l}\text { C.Sözcük Seçiminden } \\
\text { Kaynaklı Yanlışlar }\end{array}$ & $\begin{array}{l}\text { D.İmla Yazım Noktalama } \\
\text { Yanlışları }\end{array}$ \\
\hline $\begin{array}{l}\text { 1.Ses bilgisi yanlışları } \\
\text { (21) }\end{array}$ & $\begin{array}{l}\text { 1.Özne-yüklem } \\
\text { uyumsuzluğu }\end{array}$ & 1.Yanlış sözcük kullanımı & $\begin{array}{l}\text { 1.Büyük/Küçük harflerin } \\
\text { yazımı }\end{array}$ \\
\hline $\begin{array}{l}\text { 2.Biçim bilgisi } \\
\text { yanlışları (69) }\end{array}$ & $\begin{array}{l}\text { 2.Öğelerin yanlış } \\
\text { Siralanması }\end{array}$ & 2.Sözcüklerin yanlış yazımı & 2.Özel adların yazımı \\
\hline & $\begin{array}{l}\text { 3.Yanlış sözcük } \\
\text { kullanımı }\end{array}$ & & $\begin{array}{l}\text { 3.Noktalama işaretlerinin } \\
\text { kullanımı }\end{array}$ \\
\hline & & 4.Edat, bağlaç, soru \\
& & & ifadelerinin yazımı \\
\hline
\end{tabular}

Dilbilgisi yanlışlarının dağılımı incelendiğinde öğrencilerin Türkçe ses bilgisiyle ilgili 21, Türkçe biçim bilgisiyle ilgili 69 yanlış yaptıkları tespit edilmiştir. Söz dizimi yanlışlarını ise özne-yüklem uyumsuzluğu kaynaklı yanlışlar, cümle öğelerinin yanlış sıralanmasından kaynaklı yanlışlar ve yanlış sözcük kullanımı ya da sözcüklerin yanlış yazımından kaynaklı yanlışlar olmak üzere sınıflamak mümkündür.

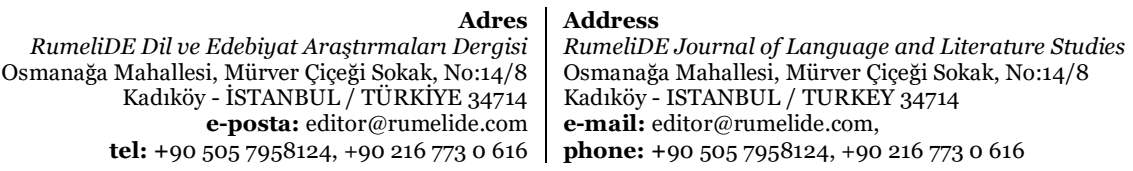


Öğrencilerin yazılı metinlerinde araştırmacı tarafından tespit edilen sözcük seçiminden kaynaklı yanlışlar ise yanlış sözcük kullanımı ve sözcüklerin yanlış yazımı şeklinde iki gruba ayrılmaktadır. İmla, yazım ve noktalama ile ilgili tespit edilen yanlışları büyük/küçük harf yazımıyla ilgili yanlışlar, özel adların yazımıyla ilgili yanlışlar, noktalama işaretlerinin yanlış kullanımı ve kullanılmamasıyla ilgili yanlışlar, edat ve bağlaçların, soru ifadelerinin yazımıyla ilgili yanlışlar olarak sıralamak mümkündür.

\section{İkinci araştırma sorusuna yönelik bulgular}

Bu bölümde öğrencilerin yaptıkları diller arası aktarım yanlışlarıyla ilgili bulgulara yer verilecektir. Cezayir 2 Üniversitesindeki Türkoloji bölümü öğrencileri yukarıda da belirtildiği üzere ülkede resmi dil ve eğitim dili olan Arapça ve Fransızcayı günlük hayatlarında kullanmaktadırlar. Hatta çoğunlukla bu iki dilin karışımı olan ve adına "Derce" denilen kreol olarak tarif edebileceğimiz bir dili kullanarak iletişim ve etkileşim kurdukları araştırmacı tarafından sahada yapılan gözlemlerde tespit edilmiştir. Yine yukarıda belirtildiği üzere araştırma grubunu oluşturan öğrenciler diğer çoğu Cezayirli gibi okulda İngilizce, Almanca, İtalyanca, İspanyolca, Rusça, Çince, Korece gibi dillerin yabancı dil olarak öğrenimine yönelik eğitim almaktadırlar. Dolayısıyla öğrencilerin Türkçe yazılı anlatımlarında yaptıkları diller arası olumsuz aktarım yanlışlarını tespit ve analiz ederken onların dillerle ilgili bu birikimlerini dikkate almak gerekmektedir.

Öğrencilerin öncelikle Arapça ve Fransızcanın etkisiyle bu dillerdeki kuralları ve yapıları Türkçe yazılı anlatımda kullanmaya yönelik davranışları sonucu oluştuğu düşünülen yanlışları şu şekilde gruplamak ve örneklendirmek mümkündür:

Öğrencilerde bildikleri dillerden hareketle çokluk anlamı verilmek istenen sözcükten önce çokluk ifade eden bir sözcük gelip gelmediğine bakılmaksızın ilgili sözcüklerde çokluk eki kullanma şeklinde bir algı oluştuğu düşünülmektedir. Bu algıdan hareket eden öğrencilerin Türkçe yazılı anlatımlarında çokluk eki kullanımıyla ilgili “iki elmalar, bazıları insanlar” benzeri birtakım yanlışlar yaptıklarını söylemek mümkündür. Söz konusu yanlışlara ilişkin bulgular aşağıda verilmiştir:

“yemekleri yerler adıları" (yemek yer adları" (Ö7)

“çokfazla adamlar" (Ö14)

“bazı yüzler” (bazlları yüzer) (Ö14)

“Alkol, sigara çok zararları yapabilirlar" (Alkol sigara çok zarar verebilirler.) (Ö18)

Öğrencilerin bildikleri dillerden yaptıkları olumsuz aktarımlar sonucunda Türkçe yazılı anlatımla ilgili yanlış yaptıkları konulardan biri de Türkçeye giren yabancı sözcüklerin yazımıdır. Öğrenciler bu konuda kelimenin Türkçesini yazmak, kelimenin Türkçesinin yazılışını değil söylenilişini ya da okunuşunu yazmak, kelimenin Arapça, Fransızca ve bazen İngilizcedeki yazımını kullanmak gibi davranışlar sergilemektedir. Konuyla ilgili tespit edilen bulgular şöyledir:

"bir amaliya yapmak karar verdi" (bir iş yapmaya karar verdi) (Ö1)

“Romantic bir film" (Ö1)

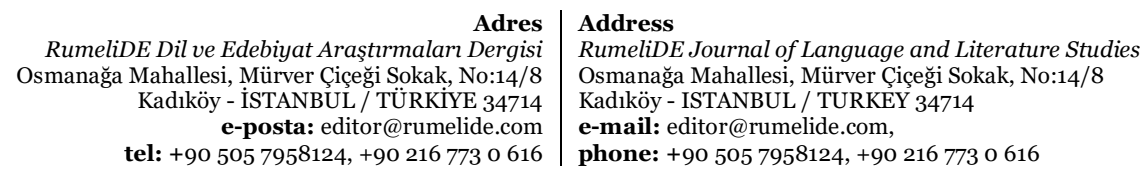


The evaluation of b1-b2 level written expressions of Algerian Turcology department students learning Turkish as a foreign language using error analysis approach / M. Emek (pp. 77-92)

"O günden (sonra) her Cuma günü piano (piyano) çalmaya başlarım (başladım) sonra konferans(lar) başlar (başladı).” (Ö2)

“Alkol ve sigara çok tahlekli (tehlikeli) sağlimiz (sağh̆ğımız) için.” (Ö5)

“çünkü fasahatı lisan konuşar” (Çünkü açık bir dil konuşur.) (Ö9)

“tehlil” (tahlil) (Ö9)

"sport vakit ayrabiliriz" (spora vakit ayırabiliriz) (Ö12)

“cazayırdan daha bir ülk Görmem” (Henüz Cezayir'den başka bir ülke görmedim) (Ö14)

“çünkü adam denizde psyoholojik ve nefsya iyi olacak." (Çünkü insan denizde psikoloji ve ruh olarak iyi olacak.) (Ö14)

"çünkü kendimden Aşk dizisileri çok sevmiyorum, tek şey beni cezbetti Şahsiyatlar" (Çünkü ben aşk dizileri çok sevmiyorum, beni cezbeden tek şey oyunculardı.” (Ö16)

"tavsiya", "tevsiye" (tavsiye) (Ö17)

"Alkol, sigara içmek bitmez lazım, Çocuklar, gençler ve hepsi şahis dünyada ve çevre himayat için" (Dünyadaki çocukların, gençlerin, bütün insanların ve çevrenin korunması için alkol ve sigara kullanımının bitmesi lazım.) (Ö18)

"ve en önemli problemi Onları hava kirliliği taasır etmek" (ve onların en önemli zararı hava kirliliğine neden olmak) (Ö18)

"Sigarat" (sigara) (Ö20)

Arapça yazımda büyük harf küçük harf ayrımı bulunmamaktadır. Yazılı anlatımda harfler sürekli cümle içerisinde aynı şekilde yazılmaktadır. Öğrencilerin Türkçe yazılı anlatımda büyük ve küçük harf kuralıyla ilgili yaptıkları yanlışların Arapçadan yaptıkları olumsuz transfer sonucu olduğu düşünülmektedir. Konuyla ilgili tespit edilen bazı bulgular aşağıda verilmiştir:

“osman bey ortoğrulun oğlusu” (Osman Bey Ertuğrul'un oğlu) (Ö4)

"önceden küçük ve Ayrllk bir Beylikıydi o toplanmıştı ve kurmuştu" (Osman Bey küçük ve diğerlerinden ayrı olan beyliğini toplayarak Osmanlı Devletini kurmuştu.” (Ö4)

“bütün denizleRi(n), dağlaRı(n), topraKlaRı(n), tek biR sahibi vaRdır.”(Ö6)

"Bu devlet Tüm dünyada (dünyayı) etkiledi” (Ö7)

“kaptan derye Hayreddin barbarus" (Kaptan-1 Derya Hayrettin Barbaros) (Ö13)

Arapça, Fransızca ve İngilizcede cümle kurulumunda sıralama özne, yüklem ve diğer öğeler şeklindedir. Türkçede ise özne başta ve yüklem sondadır. Cümle kurulumundaki sıralamada görülen bu farklılık öğrenilen yabancı dilde cümle kurulumuyla ilgili özellikle başlangıç düzeyinde birtakım yanlışların

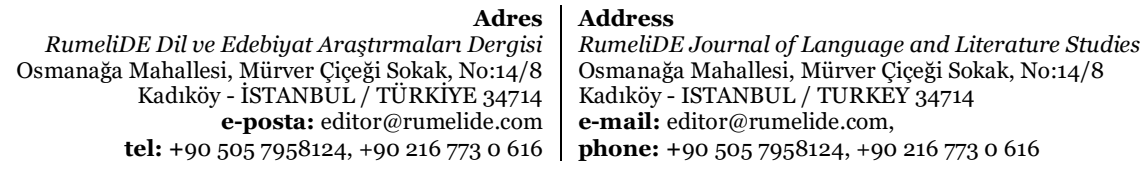


yapılmasına neden olmaktadır. Yine Arapça cümle kurulumunda yüklemi isim olan cümlelere Türkçedeki gibi “-dIr, -dUr” ekinin gelmemesi ve yüklemin yalın kullanılması bir diğer farklı uygulamadır. Öğrencilerin Türkçe cümle kurulumuna, söz dizime yönelik yaptıkları bazı yazılı anlatım yanlışlarında Arapça cümle kurulumuyla ilgili bu bilgilerinin etkisi olduğu söylenebilir. Araştırmacı tarafından tespit edilen cümle kurulumuyla ilgili yapılan yanlışların yer aldığı bulgulardan bazıları şu şekildedir:

"Hattrlyorum ki o gün Cuma günü, İstanbul'ta bir kültürel ve Gençler merkezi ismi TURİNG o gün ilk konferan hazır bulunduk." (İstanbul'da ismi TURİNG olan bir gençlik ve kültür merkezinde ilk konferansı dinlemek için hazır bulunduğumuzda günlerden Cuma idi diye hatırlıyorum.) (Ö2)

"Alkol ve sigara çok zararlar bize veriyorlar. Alkol ve sigara çok tahlekli (tehlikeli) sağlimiz (sağhlğımız) için.” (Ö5)

“onlarn tek amacı dünyada dört biR tarafta adalet surdurmek” (adaleti sürdürmekti) (Ö6)

“her şeyler var içinde” (İçinde her şey vardır.) (Ö8)

“2013 yılında okuduğum bir kitabı...” (anlatacağım/tanıtacağım) (Ö9)

“Osmanlı döneminde en meşhur sanatları (sanatlar) minyatür ve tezhip...” (tezhiptir) (Ö10)

"O gün çok güzel(di) ve güneşli(ydi), deniz çok güzel(di) resim gibi(ydi) sakin(di) ve Altın renkli konlar (tonlar vardı) çok beğendim.” (Ö14)

"Sigara, alkol birinci sebap Toplum'n problemleri için" (Alkol ve sigara toplumun problemleri için birinci sebeptir.) (Ö18)

\section{Üçüncü araştırma sorusuna yönelik bulgular}

Yanlış çözümlemesi yaklaşımın ikinci aşaması olan dil içi gelişimsel yanlışlar, dil içi aktarım yanlışlarıyla ilgili tespit edilen bulgulara bu bölümde yer verilecektir. Yabancı dil olarak Türkçe öğrenen Türkoloji bölümü öğrencilerinin aşırı genelleme, kural kısıtlamalarını bilmeme, yanlış kavram geliştirme ve kuralları eksik uygulama davranışları sonucunda yaptıkları yazılı anlatım yanlışlarının yer aldığı bu bölüm onların Türkçe dilbilgisi kurallarını bilme ve uygulama yeteneklerini ortaya koyması açısından önemlidir.

İlk olarak Türkçenin ses bilgisine yönelik yapılan yanlışlar ele alınacaktır. Arapçada ünlüler, sesli harfler okuma ve yazmada hareke adı verilen işaretlerle verilmektedir. Alfabede onları harf olarak karşılayan bir sembol bulunmamaktadır. Fransızcada ve İngilizcede ise Türkçedeki “ü, ı, ö" seslerini karşılayan bir harf bulunmamaktadır. B1-B2 düzeyi yabancı dil olarak Türkçe öğrenen Türkoloji bölümü öğrencilerinin dil içi gelişimsel yanlışlarına bakıldığında gerek bildikleri dillerin ünlülerle ilgili böyle bir yapısının olması gerekse Türkçedeki ünlülerle ilgili yeterli öğrenme sağlayamamaları sonucunda yazılı anlatımlarında bazı yanlışların olduğu tespit edilmiştir. Ünlü uyumu, ünsüz benzeşmesi, kaynaştırma ünsüzü, ünlü daralması yazılı anlatım yanlışı yapılan diğer ses bilgisi konularıdır. Öğrencilerin Türkçe yazılı anlatımda Türkçenin ses bilgisi ve özellikle Türkçede bulunan ünlülerin yazımıyla ilgili yaptıkları yanlışlarla ilgili belirlenen bulgular şu şekildedir:

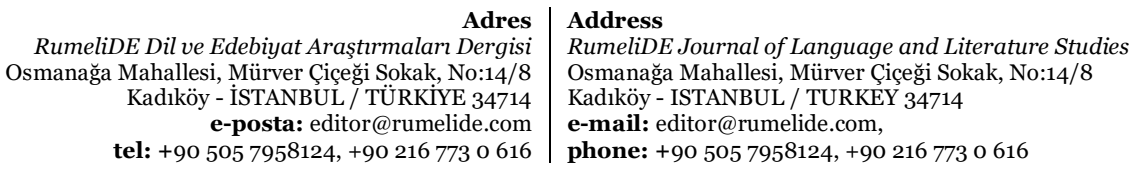


The evaluation of b1-b2 level written expressions of Algerian Turcology department students learning Turkish as a foreign language using error analysis approach / M. Emek (pp. 77-92)

"İstanbul'ta" (Ö2)

“üslübü”, “kultur”, “Füzülü” (Ö3)

“osmanli”, "sinirlerini” (sınırlarını) (Ö4)

“Hayatimizdeki”, "sağlimiz” (sağlı̆̆ımız) (Ö5)

“kötusu” (kötüsü), “surdurmek” (sürdürmek) (Ö6)

“aliş veriş”, “çok ücüz” (çok ucuz) (Ö8)

“buyudu” (büyüdü) (Ö11)

“filodu" (filoydu) (Ö13)

“küvveti” (Ö13)

“mühteşem” (Ö13)

"keyflidi” (keyifliydi) (Ö15)

“abrmla” (ağabeyimle) (Ö15)

"hayir deyeceğim" (hayır diyeceğim) (Ö15)

“çok zararları yapabilirlar" (Ö18)

“hayatdir" (Ö19)

Bulgulara bakıldığında "üslübü, Füzülü, ücüz, küvveti, mühteşem” sözcüklerinin Arapçadan dilimize geçmiş olmasına ve Türkçe ünlü harf kullanımı gerektirmemesine rağmen Türkçedeki ünlülerle yazıldığı görülmektedir. Bu durum kuralın aşırı genellenmesi ya da kural kısıtlamalarının bilinmemesiyle açiklanabilir.

Dil içi gelişimsel yanlış olarak değerlendirilebilecek ve öğrencilerin metinlerinde görülen bir diğer yazılı anlatım yanlışı ise eklerin kullanımıyla ilgilidir. Öğrencilerin isim-fiil, sıfat-fiil, ilgi, iyelik, hal ve tamlama eklerini kullanmama ya da yanlış kullanma gibi davranışlar sergilediği tespit edilmiştir. Konuyla ilgili ulaşılan bulguların bazıları şu şekildedir:

“O film adı "Sadece Sen"” (Ö1)

"bir adamı aşık oldu" (Ö1)

“ama en önemli bu” (Ö2)

"huzur(lu) ve rafah (rahat) hayat yaşamışlar" (Ö3)

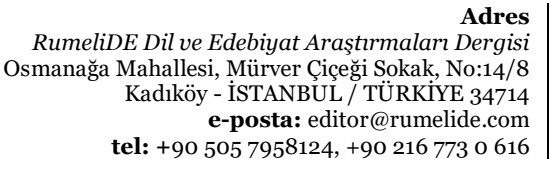

Adres RumeliDE Dil ve Edebiyat Araştırmaları Dergisi
Osmanağa Mahallesi, Mürver Ciçeği Sokak, No:14/8 Kadiköy - ISTANBUL/TURKIYE 34714 tel: +90 $5057958124,+902167730616$
Address

RumeliDE Journal of Language and Literature Studies Osmanağa Mahallesi, Mürver Çiçeği Sokak, No:14/8

Kadıköy - ISTANBUL / TURKEY 34714

e-mail: editor@rumelide.com,

phone: +90 505 7958124, +90 2167730616 


\begin{abstract}
"Hayatimizdeki”, "tahlekli” (tehlikeli), "sağlimiz” (sağhlğımız), "ruhsel gerelim” (ruhsal gerilim), "bezim Amacimiz”, "sigarat” (sigara) (Ö̈)

“bütün denizleRi(n), dağlaRı(n), topraKlaRı(n), tek biR sahibi vaRdır.”(Ö6)

“ölüm(den) uzaklaşı”” (Ö20)
\end{abstract}

\title{
Tartışma, sonuç ve öneriler
}

Cezayir 2 Üniversitesi Türkoloji Bölümü öğrencilerinin B1-B2 düzeyi yabancı dil olarak Türkçe öğrenimleri sırasında yaptıkları yazılı anlatım yanlışlarının tespitini, değerlendirilmesini ve yapılan yanlışların nedenlerini ortaya koymak, yanlışların ortadan kaldırılması konusunda çözüm önerileri geliştirmek amacıyla yapılan bu çalışmanın sonuçları konuyla ilgili daha önce yapılan araştırmaların sonuçlarıyla tartışmalı bir şekilde sunulacaktır.

Türkoloji bölümü öğrencilerinin Türkçe yazılı anlatımlarında toplam 337 yanlış tespit edilmiştir. Bu yanlışların dağılımına bakıldığında en fazla yanlışın imla, yazım ve noktalama (92 yanlış, \%37 yanlış oranı) ile Türkçe dilbilgisi (90 yanlış, \%37 yanlış oranı) konularında yapıldığı tespit edilmiştir. Daha sonra sırasıyla yazılı anlatım yanlışı yapılan konuların sözdizimi (40 yanlış, \%16 yanlış oranı) ve sözcük kullanımı (25 yanlış, \%10 yanlış oranı) olduğu görülmüştür. Dilbilgisiyle ilgili yazım yanlışı yapılan konular ses bilgisi (21 yanlış) ve biçim bilgisi (69 yanlış) olarak iki alt başlığa ayrılmaktadır. Sözdizimi yanlışlarının özne-yüklem uyumsuzluğu, cümle öğelerinin yanlış sıralanması ve yanlış sözcük kullanımı gibi bir dağılım gösterdiği belirlenmiştir. Sözcük seçiminden kaynaklı yanlışlara bakıldığında öğrencilerin yanlış sözcük kullanımı ve sözcüklerin yanlış yazımı kaynaklı sorunlar yaşadığı görülmüştür. İmla, yazım ve noktalama yanlışlarının öğrencilerin büyük/küçük harf kullanım kuralına uymaması, noktalama işareti kullanmaması ya da yanlış kullanması, edat, bağlaç ve soru ifadelerinin yazımında yaptıkları yanlışlar sonucu ortaya çıktığı tespit edilmiştir. Bölükbaş (2011), 20 Arap öğrenciyle gerçekleştirdiği çalışmasında toplam 372 yanlış tespit etmiştir. Bu yanlışların dağılımı dilbilgisi, söz dizim, sözcük seçimi ve yazım, noktalama şeklindedir. İki çalışmanın ulaşılan sonuçlarının farklılık göstermesi araştırma gruplarının ve incelenen dil yeterlik düzeylerinin farklı olması ile açılanabilir. Uzdu ve Yıldız (2017) çalışmalarında A2-B2 düzeyi 65 öğrencinin metinlerinde 6156 yanlış tespit etmişler ve yanlış dağılımını en çok yanlış yapılan alandan en aza doğru yazım, biçim söz dizim, ses bilgisi ve anlambilim şeklinde sıralamışlardır. Öğrencilerin ana dilleri ve özellikleri farklılaştıkça yazılı anlatım yanlışlarının da farklılaştığını ortaya koyması açısından bu veriler önemlidir. Yine Büyükikiz ve Hasırcı (2013) ana dilleri farklı olan B2 düzeyi yabancı dil olarak Türkçe öğrenen 42 öğrenciyle gerçekleştirdikleri çalışmada 570 yazım ve noktalama, 400 dilbilgisi, 185 sözcük seçimi, 127 söz dizim yanlışı olmak üzere 1282 yanlış tespit etmişlerdir. Bu çalışmanın verilerinden de hareketle öğrencilerin ana dillerinden bağımsız olarak en çok yanlış yapılan ilk iki alanın dilbilgisi, yazım ve imla olduğu sonucu çıkarılabilir. Yurt içinde yapılan çalışmalarla Cezayir'de yapılan bu çalışmanın sonuçlarının bu açıdan benzerlik göstermesi bir diğer dikkat çekici noktadır. Yılmaz ve Bircan (2015) çalışmalarında A2 düzeyinde en çok yanlışın dilbilgisi alanında olduğunu tespit etmişlerdir. Bu durum öğrencilerin Türkçe dil yeterliliklerin henüz bağımsız kullanıcı düzeyine ulaşmamış olmasıyla açıklanabilir. Ayrıca Boylu, Güney ve Özyalçın (2017) A2 düzeyi yazılı anlatım yanlışlarını inceledikleri çalışmalarında en çok yazılı anlatım yanlışının sözcük bilgisiyle ilgili olduğunu tespit etmişlerdir. Öğrencilerin yazılı anlatımlarında yeterli sözcük kullanamamaları da yine bağımsız dil kullanıcısı düzeyine ulaşmamış olmalarıyla açıklanabilir. Bölümde bu düzeyde yabancı dil olarak Türkçe öğreten öğretmenlerin özellikle Türkçe imla, yazım ve noktalama kurallarına yönelik etkinlikler yapması yararlı

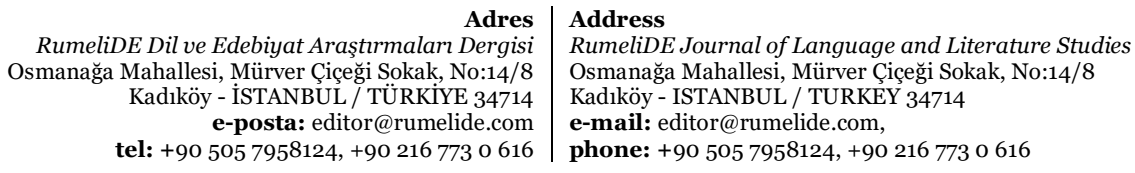


olabilir. Ayrıca bütün öğrencilerin Türkçe kelimelerin yazımıyla ve noktalama işaretleriyle ilgili yazım kılavuzu temin etmeleri sağlanabilir. Yine yazımı karıştıılan ve Türkçeye yabancı dillerden geçmiş kelimelerle ilgili listeler oluşturularak öğrencilere dağıtılabilir.

Yanlış çözümlemesi yaklaşımı kullanılarak tespit edilen diller arası olumsuz transfer yanlışlarına bakıldığında Türkoloji bölümü öğrencilerinin çok dilli olmaları her ne kadar onların diller arası olumsuz transfer yapma konusunda daha az yanlış yapacaklarını, bu konuda deneyimli olduklarını düşündürse de bu başlıkla ilgili birtakım yanlışlar tespit edilmiştir. Öğrencilerin Türkçe çokluk eki kullanımı ve Türkçe sözcüklere çokluk anlamı verme konusunda Arapça, Fransızcanın etkisinde kalarak yaptıkları yazılı anlatım yanlışlarının olduğu görülmüştür. Türkçeye giren yabancı kelimelerin yazımı konusunda öğrencilerin bu kelimeleri Türkçe okunduğu ya da söylenildiği gibi yazma, Arapçada, Fransızcada ya da İngilizcede yazıldığı, okunduğu veya söylenildiği gibi yazma şeklinde yazılı anlatım yanlışları yaptıkları belirlenmiştir. Arapçada büyük/küçük harf kullanımıyla ilgili bir kuralın olmaması öğrencilerin bu dilin etkisiyle Türkçe yazılı anlatımda büyük/küçük harf kuralıyla ilgili yanlışlar yapmalarına yol açmıştır. Son olarak Arapça, Fransızca ve İngilizcede cümle kurulumunun Türkçeye göre farklı olması ve Arapçada isim cümlelerinde yüklemin ek almaması gibi uygulama farklılıklarından dolayı öğrenciler diller arası aktarım yanlışları yapmışlardır. Subaşı (2010) ve Bölükbaş (2011) Arap Türkçe öğretim merkezlerinde yabancı dil olarak Türkçe öğrenen Arap öğrenciler ile gerçekleştirdikleri çalışmalarında diller arası olumsuz aktarım yanlışlarıyla ilgili benzer sonuçlara ulaşmışlardır. Bu durum aynı ana dilini konuşan kişilerin farklı ülkelerde yaşasalar ve farklı özelliklere sahip olsalar bile Türkçe öğrenirken benzer yanlışlar yaptıklarını göstermesi bakımından önemlidir. Öğrencilerin Türkçenin dilbilgisi ve anlam yapısını daha iyi kavrayabilmeleri, bildikleri diğer dillerden Türkçeyi ayırt edebilmeleri için derslerde diller arası karşılaştırmalı çalışmaların yapılması yararlı olabilir. Öğretmenlerin derslerde diller arasındaki kural ve anlam farklılıklarına sı sık vurgu yapması, özellikle bu dillerde ortak kullanılan sözcüklere yönelik çeşitli etkinlikler gerçekleştirmesi öğrencilerin diller arası olumsuz transfer kaynaklı yanlışlar yapmalarını önleyebilir.

Yanlış çözümlemesinin ikinci basamağı olan dil içi gelişimsel yanlışlar bağlamında Türkoloji bölümü öğrencilerinin yazılı anlatımları incelendiğinde öğrencilerin Türkçe ünlülerin yazımı, ünü daralması ve ünsüz benzeşmesi konularında yanlışlar yaptıkları belirlenmiştir. Dil içi gelişimsel yanlışlara yönelik ulaşılan sonuçlar Subaşı (2010) ve Bölükbaş'ın (2011) çalışmalarındaki sonuçlarla benzerlik göstermektedir. Ayrıca bazı öğrencilerin ünlülerin yazımına yönelik aşırı genelleme yaptıkları ve kullanılmaması gereken yerlerde bu ünlüleri kullandıkları tespit edilmiştir. Dil içi gelişimsel yanlış olarak değerlendirilebilecek ve yapılan analiz sonucu tespit edilen bir diğer yanlış yapılan konu ise Türkçe eklerin kullanımıdır. Öğrencilerin isim-fiil, sıfat fiil, ilgi, iyelik, tamlama ve hâl ekleriyle ilgili yanlışlar yaptığı görülmüştür. Çerçi, Derman ve Bardakçı (2016) çalışmalarında dilbilgisi açısından en çok yanlış yapılan alanın eklerin kullanımı olduğu sonucuna ulaşmışlardır. İki çalışmanın sonuçları bu bakımdan benzerlik göstermektedir. Bu konudaki yazılı anlatım yanlışlarını azaltmak için Türkçe ses bilgisine yönelik farklı türlerde etkinliklerin yapılması, diller arası karşılaştırmalı çalışmalar gerçekleştirilmesi yararlı olabilir.

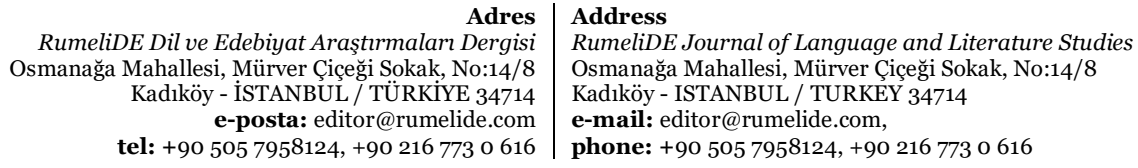

Adres
RumeliDE Dil ve Edebiyat Araşturmaları Dergisi

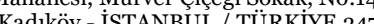
tel: +90 505 7958124, +902167730616 


\section{Kaynakça}

Boylu, E., Güney, E. Z., \& Özyalçın, K. E. (2017). Yanlış çözümleme yaklaşımına göre Türkçeyi yabancı dil olarak öğrenen b1 seviyesi öğrencilerinin yazılı anlatımlarının değerlendirilmesi. International Journal of Languages' Education and Teaching, 5(3), 184-202. http://dx.doi.org/10.18298/ijlet.1812

Bölükbaş, F. (2011). Arap öğrencilerin Türkçe yazılı anlatım becerilerinin değerlendirilmesi. Turkish Studies, 6/3, s.1357- 1367. http://dx.doi.org/10.7827/TurkishStudies.2415

Büyükikiz, K. K. \& Hasırcı, S. (2013). Yabancı dil olarak Türkçe öğrenen öğrencilerin yazılı anlatımlarının yanlış çözümleme yaklaşımına göre değerlendirilmesi. Ana Dili Eğitimi Dergisi, 1(4), 51-62. https://doi.org/10.16916/aded.15994

Corder, P. S. (1981). Error analysis and interlanguage. Oxford: Oxford University Press.

Çerçi, A., Derman, S., \& Bardakçı, M. (2016). Yabancı dil olarak Türkçe öğrenen öğrencilerin yazılı anlatımlarına yönelik yanlış çözümlemesi. Gaziantep University Journal of Social Sciences, 15(2), 695-715. https://doi.org/10.21547/jss.256710

Çetinkaya, G. (2015). Yanlış çözümlemesi: yabancı dil olarak Türkçe öğrenen b2 düzeyindeki öğrencilerin yazılı metinlerine ilişkin görünümler. International Journal of Languages' Education and Teaching, 3(1), 164-178. http://dx.doi.org/10.18298/ijlet.170

Dede, M. (1983). Yabancı dil öğretiminde karşılaştırmalı dilbilim ve yanlış çözümlemesinin yeri. Türk Dili Dergisi Dil Öğretimi Özel Sayısı, 379-380, 123-135.

Doğuman, E. (1983). Yabancı dil öğretiminde yazılı anlatım. Türk Dili Dergisi Dil Öğretimi Özel Sayısı, 379-380, 207-210.

Ekiz, D. (2009). Bilimsel araştırma yöntemleri. 2. Baskı. Ankara: Anı.

Ellis, R. (1997). Second language acquisition. Oxford: Oxford University Press.

Erdoğan, V. (2005), Contribution of error analysis to foreign language teaching. Mersin Üniversitesi Eğitim Fakültesi Dergisi, 1(2), 261-270. https://dergipark.org.tr/tr/download/article-file/161018

Hendrickson, J. M. (1980). The treatment of error in written work. The Modern Language Journal, 64 (2), 216-221. https://doi.org/10.1111/j.1540-4781.1980.tbo5188.x

İnan, K. (2014). Yabancı dil olarak Türkçe öğrenen İranlıların yazılı anlatımlarının hata analizi bağlamında değerlendirilmesi. http://dx.doi.org/10.7827/TurkishStudies.7319

Karasar, N. (2009). Bilimsel araştırma yöntemi. 20. Basım. Ankara: Nobel Yayın.

Kumar, R. (2011). Araştırma yöntemleri. 3. Baskı. Ömay Çokluk (Çev. Ed.), Ankara: Edge Akademi.

Lado, Robert (1957). Linguistics across cultures: applied linguistics for language teachers. The University of Michigan Press.

Önder, A., \& Yıldız Uzdu, F. (2017). Türkçe öğrenen yabancıların yazılı anlatım yanlışlarının çözümlenmesi. International Journal of Languages' Education and Teaching, 5(4), 100- 114. http://dx.doi.org/10.18298/ijlet.2231

Patton, M. Q. (2014). Nitel araştırma ve değerlendirme yöntemleri. Mesut Bütün, Selçuk Beşir Demir (Çev. Ed.). Ankara: Pegem Akademi.

Richards, J. C. (1974). A noncontrastive approach to error analysis. In J. C. Richards (Ed.), Error analysis (pp. 172-188). Longman Publishing.

Ulutaş, B. (2015). Doküman analizi. Seggie, F. N., \& Bayyurt. Y. (Ed.) (2015). Nitel araşttrma yöntem teknik analiz ve yaklaşımları içinde ss. 279-297. Ankara: Anı Yayıncılık.

Subaşı Adalar, D. (2010). Tömer'de yabancı dil olarak Türkçe öğrenen Arap öğrencilerin kompozisyonlarında hata analizi. Dil Dergisi, 148, 6-16. https://doi.org/10.1501/Dilder_ooooooo127

Yıldırım, A., \& Şimşek, H. (2012). Sosyal bilimlerde nitel araştırma yöntemleri. Ankara: Seçkin.

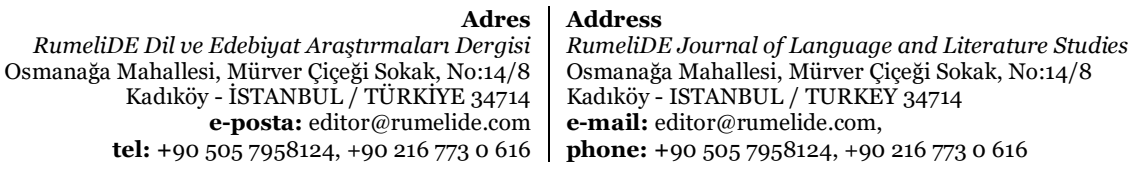


The evaluation of b1-b2 level written expressions of Algerian Turcology department students learning Turkish as a foreign language using error analysis approach / M. Emek (pp. 77-92)

Yıldız, F., \& Bircan, D. (2015). Türkçe öğretim merkezi’nde okuyan yabancı öğrencilerin yazılı kompozisyonlarının “yanlış çözümleme yöntemi”ne göre değerlendirilmesi. International Journal of Language Academy, 3(1), 113-126. http://dx.doi.org/10.18033/ijla.189 